\title{
Removal of textile dye by adsorption on the cake as solid waste from the press-extraction of the macaúba (Acrocomia aculeata) kernel oil
}

\author{
Alice Santos Caldeira ${ }^{1}$, José Domingos Fabris ${ }^{1}$, David Lee Nelson ${ }^{1}$, Sandra Matias Damasceno ${ }^{1+}$ (e) \\ ${ }^{1}$ Federal University of Vales do Jequitinhonha e Mucuri (UFVJM), 5000 MGT 367 Hwy, Km 583, Diamantina, Minas Gerais, Brazil \\ + Corresponding author: Sandra Matias Damasceno, e-mail address: sandra.matias@ict.ufvjm.edu.br
}

\author{
ARTICLE INFO \\ Article history: \\ Received: March 12, 2018 \\ Accepted: May 14, 2018 \\ Published: May 29, 2018
}

\author{
Keywords: \\ 1. adsorbent \\ 2. textile industry \\ 3. isotherms \\ 4. wastewater
}

ABSTRACT: The textile industries face difficulties in removing dyes from the liquid effluent, even after what is thought to be conventional cleaning treatments. The use of adsorbents to retain dyes in textile effluents has been showing to be a simple and promisingly efficient method. The objective of this research was to test the macaúba (Acrocomia aculeata) kernel cake as adsorbent to remove Remazol Brilliant Blue dye in batch adsorption tests. The obtained adsorption kinetic data at equilibrium were modeled by assuming both the Langmuir and the Freundlich isotherms. The values were better fitted with the Langmuir model $\left(\mathrm{R}^{2}=0.983\right)$, with a maximum adsorption capacity of $3.5 \mathrm{mg} \mathrm{g}^{-1}$ monolayer. This essay showed that the macaúba cake is an effective adsorbent to remove Remazol Brilliant Blue textile dye and it is a good alternative for treatment of textile liquid effluents.

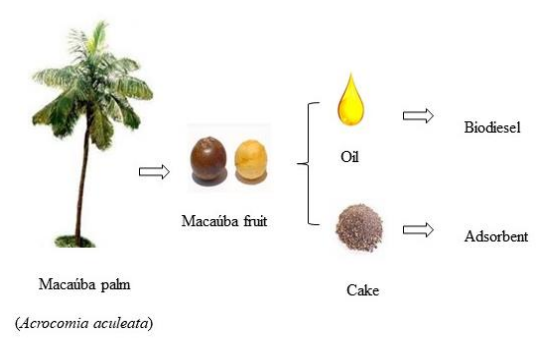

Utilization of macauba (Acrocomia aculeata) oil extraction residue as adsorbent for efllhent from the texthe intury.

\section{Introduction}

The scarcity of some natural resources, including water and feedstock, has been a major problem for textile industries. The search for alternative methods of their treatment and reuse has been growing, as it can reduce industrial costs and reduce hazardous impacts to the environment. The increasing consumption of industrial textile dyes has been responding for major environmental problems issued from industrial activities. Textile dyes are often complex organic molecules, which are usually difficult to be biologically broken down. They are to be attached to the fabric fiber to confer color to them. If these more commonly organic compounds are discharged into water bodies, they may mean real sources of pollution. Due to their recalcitrant nature, they impart long term color to the aqueous industrial effluent and reduce the penetration of sunlight, which compromises the aquatic life $\mathrm{e}^{1,2}$.

The textile industries face enormous difficulty related with the great consumption of water to accomplish several chemical processes, including those of dyeing and rinsing the fabrics. The treatment of effluents in these processes implies three main stages: primary, secondary and tertiary. In the primary treatment, the larger particles in suspension are removed by decantation. In the secondary, microorganisms are used to remove suspended particles and biodegradable matter and, finally, in the tertiary treatment, dissolved solids and residual color and odor are removed by means electrochemical process, membranes technologies, ion exchange and other technologies ${ }^{3}$. However, since the primary and secondary treatments are not efficient enough to separate very small particles, the treated fluid still leaves with staining. The steps of the textile 
processing are high costly and are not efficient enough to degrade the dye molecules. Thus, new technologies have been developed in an attempt to solve the problem of the residual staining in such effluents, even after conventional cleaning treatment.

Adsorption is putatively one of the most prospective way to treat effluents and consists of the physical or chemical interaction between the surface of a porous solid and molecules components from the fluid phase ${ }^{4,5}$. The adsorption process is mainly governed by the adsorbent properties (surface area, pore size, density, surface functional groups and hydrophobicity) of the solid material and by the adsorbate (polarity, molecule size, solubility and acidity or basicity) in the fluid, but also by some process conditions such as system temperature, the nature of the solvent and the $\mathrm{pH}$ of the medium 5 .

The solid adsorbent materials are characterized by their porous structure, which determines their high surface area. The larger the surface, the greater the adsorption efficiency ${ }^{6,7}$. Activated charcoal has been the most widely used adsorbent, regarding its high internal surface area and microporous structure, which render its high degree of surface reactivity ${ }^{8}$. Although, activated charcoal is very efficient and has many technological advantages, its use is high costly, mainly taking into account that it needs to be chemically treated to get it suitably functional. As an alternative way of minimizing process costs, agriculture crop staying or agro-industrial rejects, such as waste generated from pressing oilseed for oil extraction, sugarcane bagasse, among others have been evaluated as adsorbent for aqueous effluent due to their availability and low $\operatorname{cost}^{6,9-13}$.

The Remazol Brilliant Blue R (RBBR) dye is in the class of anthraquinone synthetic dyes and it is one of the most important dyes in the textile industry, which has been also used as a general compound model in essays of degradation studies. It is an anthracene-derived compound, highly toxic due to its polycyclic aromatic hydrocarbons (PAH), which are very difficult to be biologically metabolized ${ }^{14,15}$. The Figure 1 shows the chemical structure of RBBR dye.

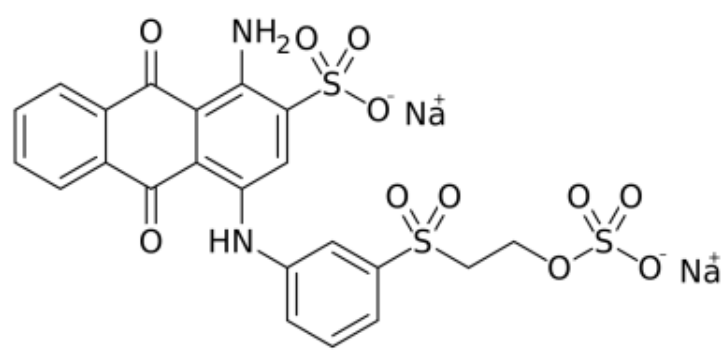

Figure 1. Chemical structure of Remazol Brilliant Blue R dye ${ }^{16}$.

The macaúba palm (Acrocomia aculeata) is a tree that can be found in several edaphoclimatic conditions of Brazil, with some predominance the cerrado biome, in Minas Gerais. The fruit is composed of the bark, the pulp, the seed (kernel) and the endocarp. Two types of oil, pulp oil and kernel oil can be extracted from macaúba fruits. It is estimated an average productivity of approximately $5 \mathrm{tha}^{-1}$ of pulp oil along with $1.4 \mathrm{t} \mathrm{ha}^{-1}$ of kernel oil for a density of 200 plants ha $^{-1}{ }^{17}$. High productivity, low production cost and good oil characteristics make it an attractive raw material for biodiesel production, generating a large amount of fruit cake from the oil press-extraction (macaúba cake) ${ }^{18}$.

In this context, this research had as objective to evaluate the residue generated in the extraction of the oil of the macaúba (Acrocomia aculeata) as adsorbent for the removal of the Remazol Brilliant Blue $\mathrm{R}$ (RBBR) dye in a simulated solution.

\section{Materials and methods}

\subsection{Preparation and characterization of the oil extraction residue}

The cake generated press-extracting the kernel oil of the macaúba (the macaúba cake, MC) used as adsorbent in these essays was provided by the Cooperativa de Agricultores Familiares e Agroextrativistas Grande Sertão Ltda, located in Montes Claros, Minas Gerais, Brazil. Initially, the cake material was washed, dried and sieved on a set of Bertel sieves; the fraction of particles larger than $212 \mu \mathrm{m}$ and smaller than $300 \mu \mathrm{m}$ was separated.

The zero-charge potential (pHpzc) of the MC was determined in duplicate by adding $50 \mathrm{mg}$ of the adsorbent material to $12.5 \mathrm{~mL}$ of the $\mathrm{KCl}$ solution $\left(0.1 \mathrm{~mol} \mathrm{~L}^{-1}\right)$. The $\mathrm{pH}$ was then varied from 1 to 14 , adjusted with dilute $\mathrm{HCl}\left(0.1 \mathrm{~mol} \mathrm{~L}^{-1}\right)$ or $\mathrm{NaOH}$ $\left(0.1 \mathrm{~mol} \mathrm{~L}^{-1}\right)$ solution, under constant stirring was for $24 \mathrm{~h}$, at $25^{\circ} \mathrm{C}$. After $24 \mathrm{~h}$, the final $\mathrm{pH}$ at equilibrium 
was determined with a bench $\mathrm{pHmeter}$. The zero-load potential of each sample was estimated by the method obtained in the range of constant $\mathrm{pH}$ (buffer effect).

\subsection{Batch adsorption essays}

The tests to check for the influence of the RBBR adsorbate concentration on the adsorption process with the macaúba cake were carried out with solutions of the dye in different concentrations $(5,10$, 20, 30, 40, $50 \mathrm{mg} \mathrm{L}^{-1}$ ) in a fixed mass of the adsorbent. The samples were placed on an orbital shaker for $24 \mathrm{~h}$ under $100 \mathrm{rpm}$. The equilibrium concentrations of the samples were measured using a UV-visible spectrophotometer. The experiment was done at constant temperature $\left(25^{\circ} \mathrm{C}\right)$.

The data for kinetic study of the adsorption process were collected at constant temperature with fixed mass of adsorbent and dye solution. The samples were collected at different contact times (5 to $1440 \mathrm{~min}$ ) between the adsorbent and the adsorbate; the concentrations of RBBR were monitored with a UV visible spectrophotometer.

\section{Results and discussion}

\subsection{Characterization of the adsorbent}

The $\mathrm{pH}_{\mathrm{pzc}}$ is one of the factors that most influence the adsorption process. The $\mathrm{pH}_{\mathrm{pzc}}$ of the adsorbent material was approximately 5.70, as shown in Figure 2.

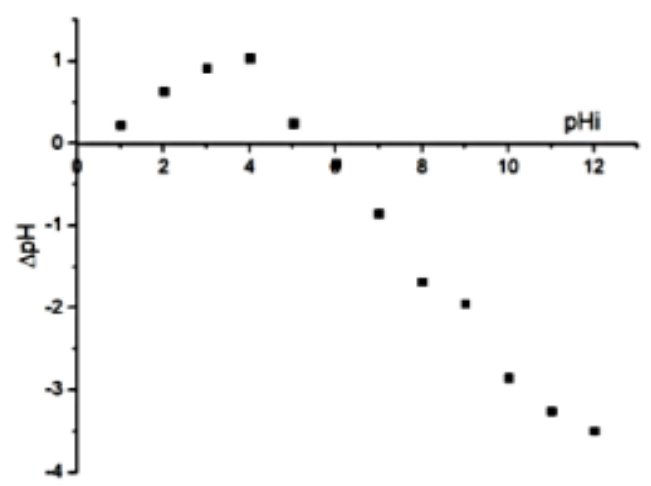

Figure 2. Point of zero charge $\left(\mathrm{pH}_{\mathrm{pzc}}\right)$ for the macaúba kernel cake.

This result indicates that the surface charges of the adsorbent become more positive as the $\mathrm{pH}$ decreases: below 5.70, the adsorbent presents a positive surface charge, favoring the adsorption of anionic species. The RBBR dye presents three sulfonated groups that give them an anionic character, possibly in the adsorption process interaction between the dye anion groups and protonated groups of the adsorbent surface, which may explain the high efficiency on removing the dye at $\mathrm{pH}$ below 5.7. The maximum initial $\mathrm{pH}$ of the solution employed in the present study was 5.0.

\subsection{Adsorption isotherms}

The adsorption capacity of the MC was determined the equation 1 ,

$$
\mathrm{q}_{\mathrm{e}}=\frac{\mathrm{C}_{0}-\mathrm{C}_{\mathrm{e}}}{\mathrm{M}} \mathrm{V}
$$

where, $\mathrm{q}_{\mathrm{e}}$ is the dye concentration adsorbed onto the cake material $\left(\mathrm{mg} \mathrm{g}^{-1}\right) ; \mathrm{C}_{0}$ is initial concentration of the textile dye in the liquid phase $\left(\mathrm{mg} \mathrm{L}^{-1}\right) ; \mathrm{C}_{\mathrm{e}}$ is equilibrium concentration of the textile dye in the liquid phase $\left(\mathrm{mg} \mathrm{L}^{-1}\right) ; \mathrm{M}$ is the mass of the cake and $\mathrm{V}$ is the volume of solution $(\mathrm{L})^{19}$.

The adsorption isotherm for textile dye onto the macaúba cake is shown in Figure 3. The curve describes the distribution of the dye molecules between the liquid and solid phases when the adsorption process reached the steady state. At equilibrium, the amount of the adsorbed dye was approximately $98 \%$.

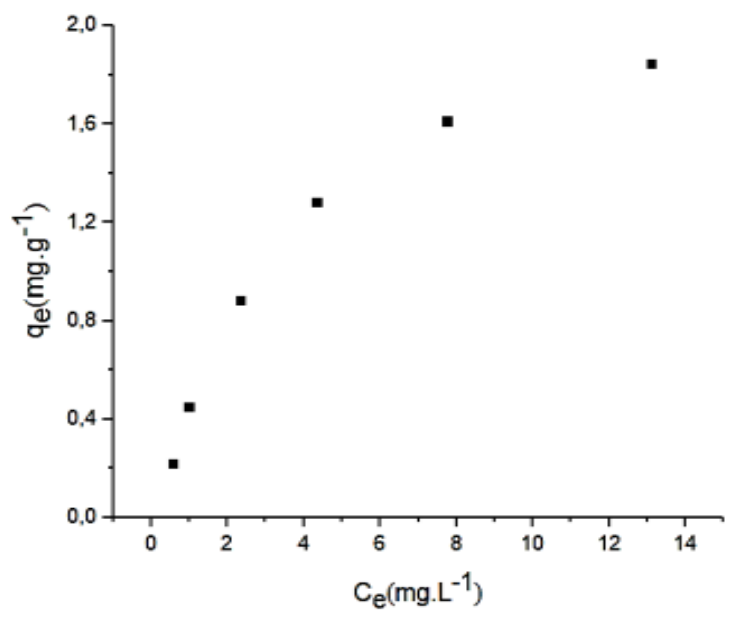

Figure 3. Adsorption isotherm for Remazol Brilliant Blue $\mathrm{R}$ on macaúba kernel cake

Two adsorption isotherm models, Langmuir and Freundlich, were used in this study to evaluate the equilibrium data. The applicability of the equation that best fitted the isotherm describing the adsorption process was indicated by the regression coefficient $\left(\mathrm{R}^{2}\right)$ criterion. The Equation 2 corresponds to the 
Langmuir model. In the equation, $\mathrm{q}_{\mathrm{e}}$ is the adsorbate concentration at equilibrium in adsorbent $\left(\mathrm{mg} \mathrm{g}^{-1}\right) ; \mathrm{k}_{\mathrm{a}}$ is Langmuir constant $\left(\mathrm{L} \mathrm{mg}^{-1}\right) ; \mathrm{q}_{\mathrm{m}}$ is the adsorbate concentration when the monolayer is formed on the adsorbent $\left(\mathrm{mg} \mathrm{g}^{-1}\right)$ surface and $\mathrm{C}_{\mathrm{e}}$ is adsorbate concentration at equilibrium in solution $\left(\mathrm{mg} \mathrm{L}^{-1}\right)^{8,20}$.

$$
\mathrm{q}_{e}=\frac{q_{m} k_{a} \mathrm{C}_{e}}{1+k_{a} C_{e}}
$$

The Langmuir isotherm is one of the most used equations for the representation of adsorption processes. This model assumes that there is a given number of sites with equivalent energy and the adsorbed molecules do not interact with one another. Although the adsorption process occurs in a monolayer, each site contains only one adsorbed molecule.

The empirical model proposed by Freundlich presumes non-ideal systems, heterogeneous surfaces and multilayer adsorption. The Freundlich isotherm is described by equation 3 ,

$$
\mathrm{q}_{\mathrm{e}}=\mathrm{K}_{\mathrm{f}} \mathrm{C}_{\mathrm{e}}^{\mathrm{n}}
$$

where $\mathrm{K}_{\mathrm{f}}$ is the sorption capacity and $\mathrm{n}$ is the sorption intensity. Results from linear regression analysis of adsorption isotherms are shown in Table 1. The choice of the isotherm model was based on the highest $\mathrm{R}^{2}$ value.

Table 1. Parameters of the Langmuir and Freundlich isotherms models for the adsorption of the RBBR dye on macaúba cake

Determination

Model

Isotherm equation

Parameters

coefficient for the linear

regression

$$
\begin{array}{ll}
\mathrm{q}_{\mathrm{e}}=\frac{\mathrm{q}_{\mathrm{m}} \mathrm{k}_{\mathrm{a}} \mathrm{C}_{\mathrm{e}}}{1+\mathrm{k}_{\mathrm{a}} \mathrm{C}_{\mathrm{e}}} & \mathrm{q}_{\mathrm{m}}=1.985 \\
&
\end{array}
$$

Langmuir

Freundlick

$$
\mathrm{q}_{\mathrm{e}}=\mathrm{K}_{\mathrm{f}} \mathrm{C}_{\mathrm{e}}^{\mathrm{n}}
$$

$$
\mathrm{K}_{\mathrm{f}}=0.721
$$

$1 / \mathrm{n}=3.798$

These coefficients provide values for $\mathrm{q}_{\mathrm{m}}(\mathrm{mg} \mathrm{g}$ ${ }^{1}$ ), which indicates the maximum adsorption capacity of the MC, and $\mathrm{k}_{\mathrm{a}}$ (adsorption constant), which is related to adsorption energy. The essential characteristic of the Langmuir isotherm can be expressed in terms of a dimensionless equilibrium parameter $\left(R_{L}\right)$, given by equation 4 , where $R_{L}$ is the magnitude that determines the viability of the adsorption process.

$$
R_{L}=\frac{1}{1+k_{a} C_{0}}
$$

Values of $R_{L}=1$ indicate a linear adsorption process of Langmuir, $\mathrm{R}_{\mathrm{L}}>1$ and $\mathrm{R}_{\mathrm{L}}<1$ refer to unfavorable and favorable adsorption, respectively, whereas the adsorption would be irreversible for $R_{L}=0$. From this study, the found value of $R_{L}=0.870$, indicating a favorable adsorption $^{21}$.

The $1 / \mathrm{n}$ parameter of the Freundlick equation ranged from 0 to 1 ; it is a measure of the adsorption intensity or of the surface heterogeneity, becoming more heterogeneous as the value approaches zero. The found value of $1 / \mathrm{n}$ from this study indicates that the adsorption process of the dye on the MC was not heterogeneous, consistently with the result obtained for the Langmuir model.

\section{Conclusions}

The adsorption of the Remazol Brilliant Blue $\mathrm{R}$ dye, in this solution model of an industrial dye aqueous effluent, onto the surface of particles from the macaúba kernel cake was investigated in a 
batch arrangement. The charge zero point (PZC) is a convenient reference for predicting the chargedependent behavior of adsorbents and their suspensions.

It was found that the Langmuir Isotherm provides the best fit to the experimental data. The value of the dimensionless parameter was evaluated as $R L=0.870$, indicating that the adsorption of RBBR on MC is a spontaneous favorable process. The adsorption isotherm for the adsorption of RBBR in MC can be well modeled by the Langmuir isotherm, with a linear regression determination coefficient of approximately $\mathrm{R}^{2}=0.98$. It can be concluded that the macaúba kernel cake has homogeneous surface energy and can be a good alternative for the cleaning treatment of textile effluents.

\section{References}

[1] Wong, Y. C., Szeto, Y. S., Cheung, W. H., McKay, G., Adsorption of acid dyes on chitosan equilibrium isotherm analyses, Process Biochem. 39(6) (2004) 695-704. https://doi.org/10.1016/S0032-9592(03)00152-3.

[2] Araújo, F. V. F., Yokoyama, L., Teixeira, L. A. C., Color removal in reactive dye solutions by UV/H2O2 oxidation, Quim. Nova 29 (1) (2006) 11-14. https://doi.org/10.1590/S010040422006000100003 .

[3] Ghaly, A. E., Ananthashankar, R., Alhattab, M., Ramakrishnan, V. V., Production, Characterization and treatment of textile effluents: A Critical Review, J. Chem. Eng. Process Technol. 5 (182) (2014) 5-18. https://doi.org/10.4172/21577048.1000182 .

[4] Gupta, V.K., Application of low-cost adsorbents for dye removal - A review. J. Environ. Manage., $90 \quad$ (2009) 2313-2342. https://doi.org/10.1016/j.jenvman.2008.11.017.

[5] Crittenden, B.; Thomaz, W. J.; Adsorption Technology and Design, Butterworth-Heinemann: Oxford, 1998.

[6] Oliveira, L. S., Franca, A. S., Low-cost adsorbents from agri-food wastes, In: Food Sci. Technol. New Res. Greco, L. V. and Bruno, M. N., New Publishers: New York, USA, 2008, Ch. 3.
[7] Rouquerol, J., Rouquerol, F., Llewellyn, P., Maurin, G., Sing, K. S.W., Adsorption by Powders and Porous Solids: Principles, Methodology and Applications, Oxford, 2nd ed., 2014, Ch.1.

[8] Bansal, R. C., Goyal, M., Activated Carbon Adsorption, CRC Press: Boca Raton, 1st ed., 2005, Ch.1.

[9] Franca, A. S., Oliveira, L. S., Oliveira, V. F., Alves, C.O., Potential use of Crambe abyssinica press cake as an adsorbent: batch and continuous studies, Environ. Eng. Manage. J., 13 (12) (2014) 3025-3036 http://omicron.ch.tuiasi.ro/EEMJ.

[10] Bhatnagar, A., Kaczala, F., Hogland, W., Marques, M., Paraskeva, C. A., Papadakis, V. G., Sillanpää, M., Valorization of solid waste products from olive oil industry as potential adsorbents for water pollution control--a review, Environ. Sci. Pollut. Res. 21 (1) (2014) 268-98. https://doi.org/10.1007/s11356-013-2135-6.

[11] Nascimento, G. E., Duarte, M. M. M. B., Campos, N. F., Rocha, O. R. S., Silva, V. L., Adsorption of azo dyes using peanut hull and orange peel: a comparative study, Environ. Technol. $35 \quad$ (9-12) (2014) 1436-1453. https://doi.org/10.1080/09593330.2013.870234.

[12] Nascimento, G. E., Duarte, M. M. M. B., Campos, N. F., Barbosa, C. M. B. M., Silva, V. L., Adsorption of the reactive gray $\mathrm{BF}-2 \mathrm{R}$ dye on orange peel: kinetics and equilibrium studies, Desalin. Water Treat. (52) (5-9) (2014) 1578-1588. https://doi.org/10.1080/19443994.2013.788457.

[13] Oliveira, R. S., Borges, M. F., Vieira, A. T., Henrique, M. A., Ribeiro, E. A. M., Bezerra, F. A., Portela, F. M., Pereira, N. R., Assunção, R. M. N., Ruggiero, R., Adsorção de contaminantes do biodiesel por fibras de bagaço modificadas na superfície, Quim. Nova (41) (2) (2017) 121-128. https://doi.org/10.21577/0100-4042.20170164.

[14] Machado, K. M. G., Matheus, D. R., Biodegradation of remazol brilliant blue $\mathrm{R}$ by ligninolytic enzymatic complex produced by Pleurotus ostreatus, Braz. J. Microbiol. (37) (4) (2006) 468-473. https://doi.org/10.1590/S151783822006000400013 . 
[15] Hadibarata, T., Kristanti, R. A., Effect of environmental factors in the decolorization of remazol brilliant blue R by Polyporus sp. S133, J. Chil. Chem. Soc. (57) (2) (2012) 1095-1098. https://doi.org/10.4067/S071797072012000200007.

[16] Ahmad, M. A., Alrozi, R., Optimization of preparation conditions for mangosteen peel-based activated carbons for the removal of Remazol Brilliant Blue $\mathrm{R}$ using response surface methodology, Chem. Eng. Sci. (165) (3) (2010) 883-889.

https://doi.org/10.1016/j.cej.2010.10.049.

[17] Clement, C.R., Pérez, E. L., Leeuwen, J. V., O potencial das palmeiras tropicais no Brasil: acertos e fracassos das últimas décadas. Agrociências,Montevideu, (9) (1-2) (2005) 67-71.

[18] Mota, C. S., Corrêa, T. R., Grossi, J. A. S., Castricini, A., Ribeirão, A. S., Exploração sustentável da macaúba para produção de biodiesel: colheita, pós-colheita e qualidade dos frutos. Informe Agropecuário: Belo Horizonte (32), 2011. Available from: http://www.informeagropecuario.com.br/produtos. php?produto=129.

[19] Itodo, A. U., Usman, A., Akinrinmade, G., Itodo, H. U., Ugboaja, V. C., Performance assessment of received and formulated carbon animalis: a comparative adsorption isotherm test, $\mathrm{J}$. Environ. Prot. (3) (3) (2012) 288-295. https://doi.org/10.4236/jep.2012.33036.

[20] Demir, H., Top, A., Balköse, D., Ülkü, S., Dye adsorption behavior of Luffa cylindrica fibers. J. Hazard. Mater. (153) (1-2) (2008) 389-942. https://doi.org/10.1016/j.jhazmat.2007.08.070.

[21] Dada, A. O., Olalekan, A. P., Olatunya, A. M., Dada, O., Langmuir, Freundlich, Temkin and Dubinin-Radushkevich Isotherms studies of equilibrium sorption of $\mathrm{Zn} 2+$ onto phosphoric acid modified rice husk, J. Appl. Chem. (3) (1) (2012) 38-45. https://doi.org/10.9790/5736-0313845. 